\title{
Model of Learning Using iLearning on Independent Study Classes at University
}

\author{
Sudaryono $^{1, *}$, Padeli $^{2}$, Erick Febriyanto ${ }^{2}$ \\ ${ }^{1}$ Department of Informatics Engineering, Raharja College, Indonesia \\ ${ }^{2}$ Department of Computer Engineering, Raharja College, Indonesia
}

Copyright $\bigcirc 2017$ by authors, all rights reserved. Authors agree that this article remains permanently open access under the terms of the Creative Commons Attribution License 4.0 International License

\begin{abstract}
Raharja College is one of the universities who apply a learning method that is quite different which does not only rely on the conventional learning system in which Teaching and Learning Activity is done by students and lecturers are required to come face to face directly, but also applying e-learning method learning or better known as iLearning system Education in Raharja College. Where the application is used several devices that support the learning system ranging from $\mathrm{iDu}$ (iLearning Education) as a medium of interaction Students and Lecturers and the Use of iLearning Media (iMe) as the media that holds the activity of learning activities through methods iLearning Education. Then over the course of this method several questions arise about how valid the system on the quality assessment and the effectiveness of learning methods where from it is necessary to apply a measuring instrument which can measure the validity of the system on the quality and effectiveness of teaching methods in College Raharja especially in class Independent Study IL101A and IL101C. By using descriptive survey research carried out in which of the survey conducted found a solution of the problem, namely the procurement of a measuring instrument in this case Viewboard which later can display historical data with certain categories where the presence Viewboard that later measurements on the validity of the system in particular in terms of learning effectiveness can be proven empirically through data accurate.
\end{abstract}

Keywords iLearning Education, Survey, Measurement, Learning Effectiveness, Viewboard

\section{Overview}

Raharja College as an institution of higher education that provides academic degree in the field of IT, is where the development of ideas and knowledge, to propagate the values of life, and the development of civilization. Through these roles, Raharja Colleges has a responsibility to give birth to a superior culture, contributes to an increase in welfare of society, elevate the dignity of humanity, and enhance the competitiveness of the nation. To achieve those goals, the College produces the best graduates Raharja claimed that is useful for society, creating a variety of products to solving problems of humanity, disseminate the results of research and other outputs that ultimately can contribute on the development of the knowledge and wisdom of the human race.

Teaching and learning should be planned so that learning takes place properly and achieve maximum results. Each planning deals with thoughts about what should be done. Teaching and learning program planning estimates for the actions which will be performed at the time of carrying out the instruction. Contents planning, i.e. set up and assign learning elements, such as the purpose, materials or contents, methods, tools and resources as well as assessment (Hamdani, 2011:56) [1].

Improvement on the abilities and expertise of the professors in the field of subject matter and methodology of learning is essential. When the College increasingly complex conditions, the size of groups of study increasingly bloated, the burden of teaching and learning are increasingly intensive and extensive learning facilities and resources, the more modern, stress levels and alienation students getting track, and work procedures the more need to enhanced, the terminology " teaching methodology " which is known for is experiencing an expansion of meaning. That is the more commonly known management class. Implicit here, initiatives to increase the effectiveness of learning lecturer at least one level better than ever necessitate the capacity to motivate and manage student (motivating and managing student) significantly. In line with that, research on how classes can be managed effectively to extract increasingly to face, more than just focusing on the behavior of college students and their learning process.

The development of information and communication technologies are rapidly encourage institutions to make use 
of the concept and design of e-learning system to enhance the effectiveness and flexibility of learning. In this study, the use of information systems-based education will be used mostly by students and teachers to interact. So either the vision or mission of the College can be realize, with the presence of this information system. Students who are less able to follow lessons will be helped by the existence of this information system. So in the development of information systems, both students and professors need to proactively involved with strategic decisions in the implementation of this application. In other words it takes active participation in the users of both students and professors, so that later developed systems can run effectively.

To overcome physical access limitations, certain institutions have leveraged the Internet to facilitate teaching international trade, building e-learning systems that include teaching videos and slides. Learners can watch the teaching videos anywhere and at any time through the Internet. They can also download and study slides and submit homework through the system. This teaching method is similar to the traditional teaching method, allowing learners to conveniently study international trade by using the Internet [2].

Untung Rahardja, the Dewi Immaniar Desrianti and Siti Mawadah (2011). States in education, especially in the IT field. To complement the basic needs IT from a method of learning, with iLearning. The students develop their mindset vying to compete to be the most future of using iLearning. iLearning to organize activity of learners to be able to continuously learn, play, work, and pray. Development of iLearning can create integrity are good for modern learning systems in the future. Thus the iLearning is good leaders for educators or learners to get accurate information and relevant can be anywhere, anytime when we learn, play, pray or work. Do 4B with just one touch of the hand. Therefore, from the above description then it takes a measurement in the framework of implementation of the system of Education and Media iLearning to be known to the validity of the system of assessment of the quality and effectiveness of learning methods that belong to the object of the study [3].

\section{Problems}

The College has a special place in various Raharja IT field which is the most important element. But still there are problems that must be faced when this foremost in all its operational activities to support management activities as well as academic. The vision and mission to be achieved by College Raharja is a prime target so that in determining the decision on design, analysis and implementation of the assessment system of Education and application system iLearning this Media, then it should be in accordance with one of the purposes of the establishment of a college education. Of the background issues that (is already constrained before, then there are three formula problems that appear in this study, namely:

1. What is the model of learning Independent Study classes of iLearning can enhance motivation?

2. How the model of learning Independent Study classes as iLearning can improve the quality of judgments?

3. How to influence the learning model iLearning so get the results of the effectiveness study by empirical evidence?

\section{Related Research}

As supporting research, hence the need for some research as support in conducting relevant research and utilized to assist in this research. There are 9 (nine) literature studies, namely:

1. "Penerapan Rinfo Sebagai Media Pendukung Untuk Proses Pembelajaran Pada Perguruan Tinggi Raharja (The application of Rinfo As Media advocates for Learning On College Raharja) [Untung Rahardja, 2014] " explains that the application i. E email Rinfo became the official email that is used by the entire civitas that exist on College Raharja to communicate with each other. Rinfo this is Gmail, which in the adaptation of the Google Platform with Raharja. Info as its domain. This is the media communication Rinfo while supporting tools in the process of learning in College Raharja. Because in addition to integrated with TPi, Rinfo also connects with other learning support tools, like Docs, Drive, Sites, and other support tools. The difference between this study is the absence of the influence of motivation and efficiency of analytical study on students and iMe [4].

2. "Pemanfaatan E-Learning Sebagai Media Pembelajaran Pada Pendidikan Tinggi Jarak Jauh (The Utilization Of E-Learning As A Medium Of Instruction In Higher Education Over Long Distances) [Pardede, 2011] " explains that Through e-learning lessons can be done without a face-to-face between teacher and learners and are no longer restricted by time and place. E-learning is becoming one of the world's problems education solutions to the increasingly busy with a variety of services that offer high flexibility and mobility. The difference between this study is the absence of influence of the analytical study on the motivation of students [5].

3. "Penggunaan Metode iLearning untuk Meningkatkan Kualitas Pembelajaran di Perguruan Tinggi (The use of methods to improve the quality of learning iLearning in College [Henderi, 2013] "to explain that the existence of shortcomings in the system of learning that can support quality teaching and learning is good and efficient. The nature conservation where learning is still running one direction where the student/ $i$ fixated on material presented by lecturers in front and makes the appropriate student/i feel tired and passive. As an alternative workaround is to provide the latest learning innovations system iLearning. The difference between 
this study is the absence of influence of the analytical study on the motivation of students [6].

From 3 (three) literature reviews above, consists of 2 (two) literature reviews discusses the iLearning relating to learning methods are used, the infrastructure that is used and the benefits resulting from the application of the method of learning the iLearning.

\section{Troubleshooting}

Systems used in this study are part of a system based on Media iLearning a CMS (Content Management System) of WordPress. WordPress is an open source application (open source) is used as a very popular blog engine (blog engine). WordPress is built using the PHP programming language and have the database from the MySQL DBMs PHP and MySQL is open source software (open source software). This is evident in Image 1 below.
This research uses a system of iLearning Media so some features already available in it, including in terms of design and design of existing systems. Therefore, this study just emphasizes the influence Model of learning Independent Study Classes On iLearning. Although in the order of the Waterfall in the System Development Life Cycle (SDLC) itself that the implementation of the system is the third stage after system analysis and system design, turns out in this series of process there is still a deficiency in terms of interest and the liveliness of students to learning effectiveness can be managed in a way that intelligence. Therefore, in accordance with the stages of the waterfall in the System Development Life Cycle (SDLC). Then it took the development of re system or design so that the purpose of the effectiveness of learning can be fulfilled properly. After a review of system designs based on level and Media iLearning needs then required in supporting the goal of this research is to add the plugin in the iLearning Media. Therefore, in this study required additional plugin PHP Code For Posts and User Role Editor.

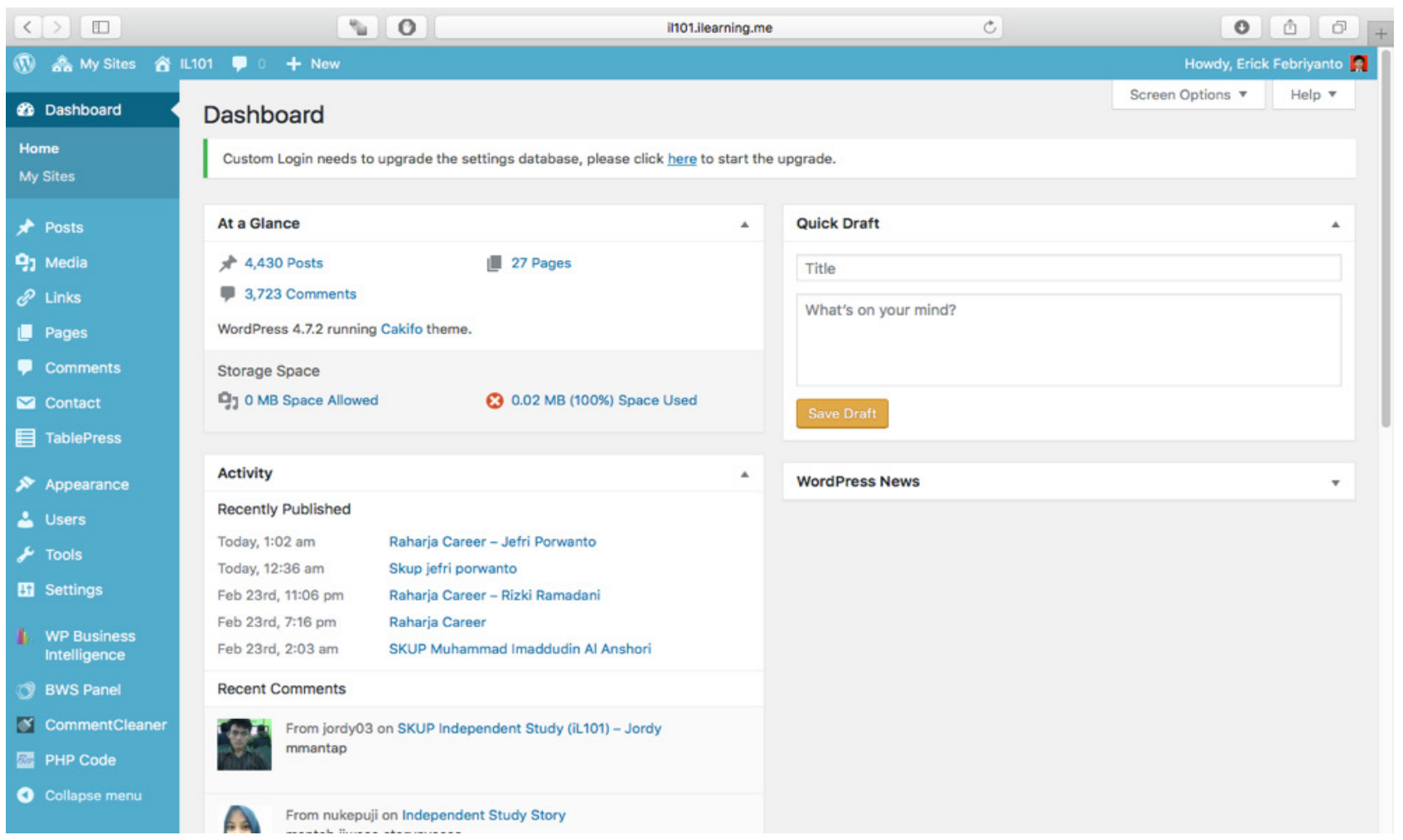

(Source: http://il101.ilearning.me/wp-admin/)

Image 1. The Dashboard System iLearning Media 
In the feasibility study needs analysis system on Raharja College. iLearning Me, the user need not view can only be accessed by the user's iMe user and admin, but widely accessible without having to go into the system of iLearning Media. Then it takes a look at the dashboard page that can be accessed by everyone (public). In Image 2 the following is the display number of comments that were in the system and can only be accessed by the user's iMe user and admin only.

By displaying the data visualization aims to ease the user both students and teachers in looking at the data and speed up the process in decision making. The operational data onto the iLearning Media development data mart display information dashboard. Operational data is the database used to store data onto the post and the comments made by teachers and students for research time lasts up to be used with unlimited time.

Based on changes to the existing system, then it needs a new system specified. Highcharts else needed to display the dashboard a dynamic chart in accordance with the existing data onto the database of iLearning Media. The next step is the design or redesign of a system to repair or renew the old system as well as providing a clear picture on the users of the system design process of beginning to end.

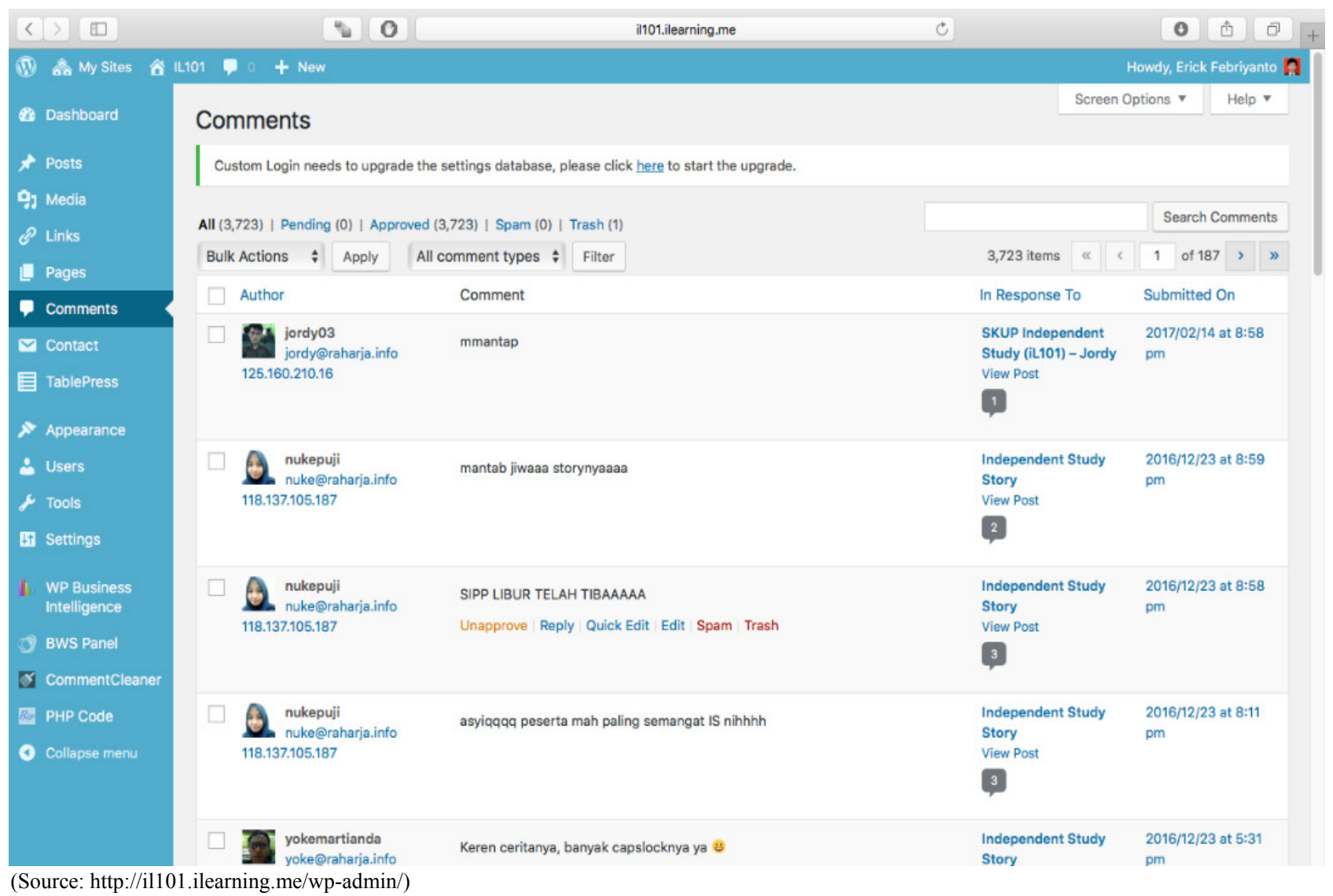

(Source: http://il101.ilearning.me/wp-admin/)

Image 2. Comment the iLearning Media 

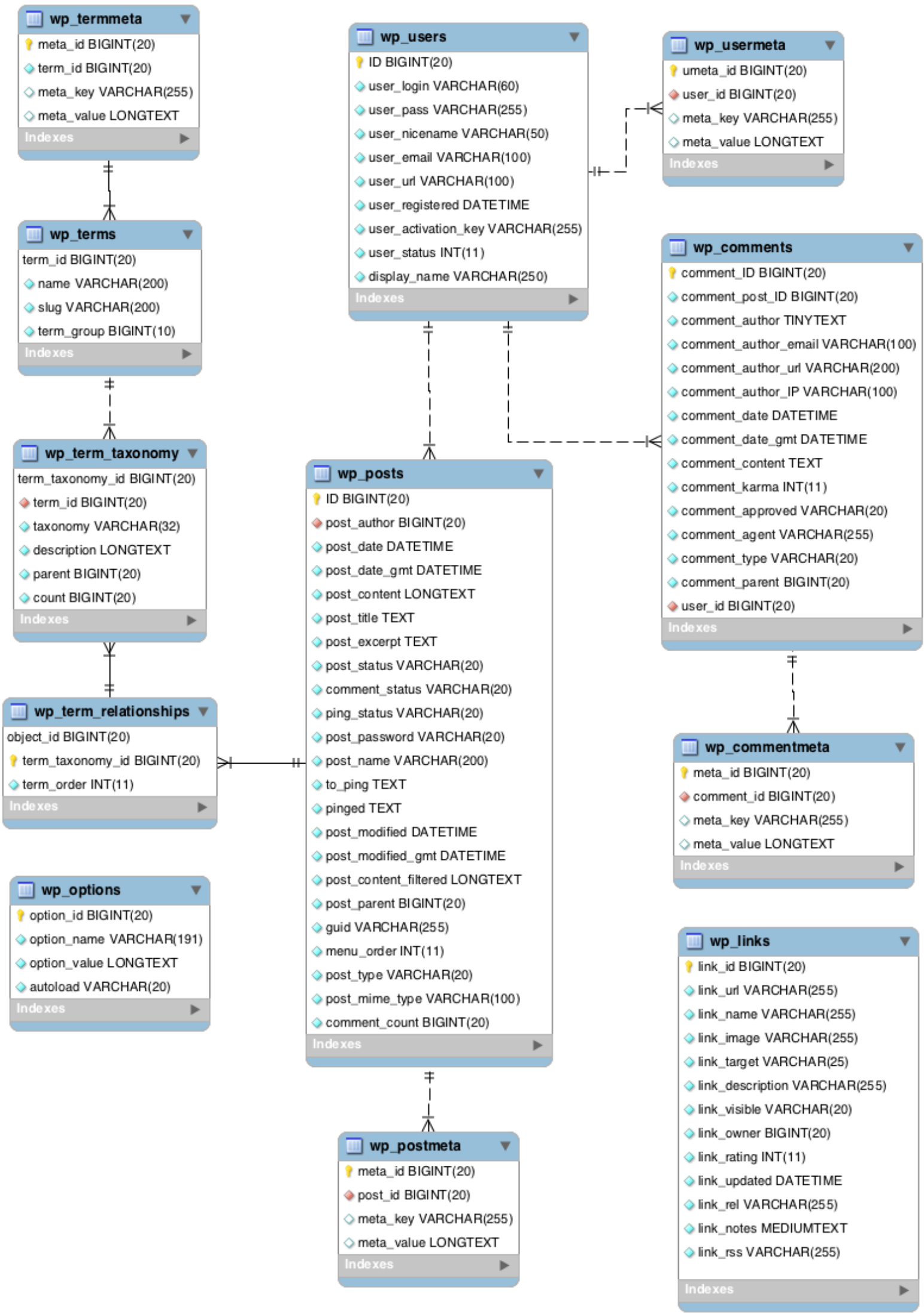

(Source: https://codex.wordpress.org/File:WP4.4.2-ERD.png)

Image 3. Standard tables in the operational Database WordPress 
Image 3. the above provides an overview of visual database operations WordPress or iLearning Media and the relationships between the tables created during the standard installation of WordPress.

\subsection{The Tables}

- $\quad$ wp posts

- $\quad$ wp_postmeta

- wp_comments

- wp_commentmeta

- wp_terms

- wp_term_taxonomy

- wp_term_relationships

- wp_users

- wp_usermeta

- wp_options

- wp_links

\section{2. wp_posts}

The posts table is arguably the most important table in the database. Its name sometimes throws people who believe it purely contains their blog posts. However, albeit badly named, it is an extremely powerful table that stores various types of content including posts, pages, menu items, media attachments and any custom post types that a site uses.

The table's flexible content nature is provided by the 'post type' column which denotes if the row is a post, page, attachment, nav_menu_item or another type. But this flexibility also makes it hard to discuss and describe. Essentially the table contains rows of content objects with different types, but for ease of reading, I will refer to the rows as "posts" throughout this article.

- ID - unique number assigned to each post.

- $\quad$ post_author - the user ID who created it. (Reference to the wp_users table.)

- post date - time and date of creation.

- post_date_gmt - GMT time and date of creation. The GMT time and date is stored so there is no dependency on a site's timezone in the future.

- post_content - holds all the content for the post, including HTML, shortcodes and other content.

- post_title - title of the post.

- post_excerpt - custom intro or short version of the content.

- $\quad$ post_status - status of the post, e.g. 'draft', 'pending', 'private', 'publish'. Also a great WordPress news site.

- comment_status - if comments are allowed.

- ping_status - if the post allows ping and trackbacks.

- $\quad$ post_password - optional password used to view the post.

- $\quad$ post_name - URL friendly slug of the post title.

- to_ping - a list of URLs WordPress should send pingbacks to when updated.
- $\quad$ pinged - a list of URLs WordPress has sent pingbacks to when updated.

- $\quad$ post_modified - time and date of last modification.

- post_modified_gmt - GMT time and date of last modification.

- $\quad$ post_content_filtered - used by plugins to cache a version of post_content typically passed through the 'the content' filter. Not used by WordPress core itself.

- $\quad$ post_parent - used to create a relationship between this post and another when this post is a revision, attachment or another type.

- $\quad$ guid - Global Unique Identifier, the permanent URL to the post, not the permalink version.

- menu_order - holds the display number for pages and other non-post types.

- $\quad$ post_type - the content type identifier.

- post_mime_type - only used for attachments, the MIME type of the uploaded file.

- comment_count - total number of comments, pingbacks and trackbacks.

\section{3. wp_postmeta}

This table holds any extra information about individual posts. It is a vertical table using key/value pairs to store its data, a technique WordPress employs on a number of tables throughout the database allowing WordPress core, plugins and themes to store unlimited data.

- meta_id - unique number assigned to each row of the table.

- post_id - the ID of the post the data relates to. (Reference to the wp posts table.)

- meta_key - an identifying key for the piece of data.

- $\quad$ meta_value - the actual piece of data.

\section{4. wp_comments}

Any post that allows discussion can have comments posted to it. This table stores those comments and some specific data about them. Further information can be stored in wp_commentmeta.

- comment_ID - unique number assigned to each comment.

- comment_post_ID - ID of the post this comment relates to. (Reference to the wp_posts table.)

- comment_author - Name of the comment author.

- comment_author_email - Email of the comment author.

- comment_author_url-URL for the comment author.

- comment_author_IP - IP Address of the comment author.

- comment_date - Time and data the comment was posted.

- comment_date_gmt - GMT time and data the comment was posted.

- comment_content - the actual comment text. 
- comment_karma - unused by WordPress core, can be used by plugins to help manage comments.

- comment_approved - if the comment has been approved.

- comment_agent - where the comment was posted from, eg. browser, operating system etc.

- comment_type - type of comment: comment, pingback or trackback.

- comment_parent - refers to another comment when this comment is a reply.

- user_id - ID of the comment author if they are a registered user on the site. (Reference to the wp_users table.)

\section{5. wp_commentmeta}

This table stores any further information related to a comment.

- $\quad$ meta_id - unique number assigned to each row of the table.

- comment_id - the ID of the post the data relates to. (Reference to the wp_comments table.)

- meta_key - an identifying key for the piece of data.

- meta value - the actual piece of data.

\section{6. wp_terms}

Terms are items of a taxonomy used to classify objects. Taxonomy what? WordPress allows items like posts and custom post types to be classified in various ways. For example, when creating a post in WordPress, by default you can add a category and some tags to it. Both 'Category' and 'Tag' are examples of a taxonomy, basically a way to group things together.

To classify this post (how meta of me) I would give it a category of 'Guide' and tags of 'database' and 'mysql'. The category and tags are terms that would be contained in this table.

- term_id - unique number assigned to each term.

- name - the name of the term.

- $\quad$ slug - the URL friendly slug of the name.

- term_group - ability for themes or plugins to group terms together to use aliases. Not populated by WordPress core itself.

\section{7.wp_term_taxonomy}

Following the wp_terms example above, the terms 'Guide', 'database' and 'mysql' that are stored in wp_terms don't exist yet as a 'Category' and as 'Tags' unless they are given context. Each term is assigned a taxonomy using this table.

The structure of this table allows you to use the same term across different taxonomies. For example 'Database' could be used as a category for posts and as a term of a custom taxonomy for a custom post type (think portfolio category for portfolio items). The term of Database would exist once in wp_terms, but there would be two rows in wp_term_taxonomy for each taxonomy.

- term_taxonomy_id - unique number assigned to each row of the table.

- term_id - the ID of the related term. (Reference to the wp_terms table.)

- taxonomy - the slug of the taxonomy. This can be the built in taxonomies or any taxonomy registered using register_taxonomy().

- description - description of the term in this taxonomy.

- $\quad$ parent - ID of a parent term. Used for hierarchical taxonomies like Categories.

- count - number of post objects assigned the term for this taxonomy.

\section{8.wp_term_relationships}

So far we have seen how terms and their taxonomies are stored in the database, but have yet to see how WordPress stores the critical data when it comes to using taxonomies. This post exists in wp_posts and when we actually assign the category and tags through the WordPress dashboard this is the junction table that records that information. Each row defines a relationship between a post (object) in wp_posts and a term of a certain taxonomy in wp_term_taxonomy.

- object_id - the ID of the post object. (Reference to the wp posts table.)

- term_taxonomy_id - the ID of the term / taxonomy pair. (Reference to the wp_term_taxonomy table.)

- term_order - allow ordering of terms for an object, not fully used.

\section{9. wp_users}

WordPress' user management is one of its strongest features and one that makes it great as an application framework. This table is the driving force behind it.

- $\quad$ ID - unique number assigned to each user.

- user_login - unique username for the user.

- user_pass - hash of the user's password.

- user_nicename - display name for the user.

- user_email - email address of the user.

- user_url-URL of the user, e.g. website address.

- user_registered - time and date the user registered.

- user_activation_key - used for resetting passwords.

- user_status - was used in Multisite pre WordPress 3.0 to indicate a spam user.

- display_name-desired name to be used publicly in the site, can be user_login, user_nicename, first name or last name defined in wp_usermeta.

\subsection{0. wp_usermeta}

This table stores any further information related to the users. You will see other user profile fields for a user in the 
dashboard that are stored here.

- umeta_id - unique number assigned to each row of the table.

- user_id - ID of the related user. (Reference to the wp_users table.)

- $\quad$ meta_key - an identifying key for the piece of data.

- meta_value - the actual piece of data.

\subsection{1.wp_options}

The options table is the place where all of the sites configuration is stored, including data about the theme, active plugins, widgets, and temporary cached data. It is typically where other plugins and themes store their settings.

The table is another example of a vertical key/value pair table to allow it to store all sorts of data for a variety of purposes.

- option_id - unique number assigned to each row of the table.

- option_name - an identifying key for the piece of data.

- option_value - the actual piece of data. The data is often serialized so must be handled carefully.

- autoload - controls if the option is automatically loaded by the function wp load_alloptions() (puts options into object cache on each page load).

Did you know that when performing migrations of databases using WP Migrate DB Pro you can tell the plugin to preserve specific options in the target database using the 'wpmdb_preserved_options' filter?

\subsection{2. wp_links}

During the rise of popularity of blogging having a blogroll (links to other sites) on your site was very much in fashion. This table holds all those links for you.

Nowadays blogrolls are used less and less and as of WordPress 3.5 the administration of links was removed from the admin UI. The table remains in the database for backwards compatibility and you can use the old link manager UI using this plugin.

- link_id - unique number assigned to each row of the table.

- link_url-URL of the link.

- link_name - name of the link.

- link_image - URL of an image related to the link.

- link_target - the target frame for the link. e.g. _blank, top, none.

- link_description - description of the link.

- link_visible - control if the link is public or private.

- link_owner - ID of user who created the link. (Reference to the wp_users table.)

- link_rating - add a rating between 0-10 for the link.

- link_updated - time and date of link update.

- link_rel - relationship of link.

- link_notes - notes about the link.

- link_rss - RSS address for the link.

The next Image 4. below gives you an idea, visual additional operational data base tables in WordPress or iLearning Media is closely related to WordPress Multisite.

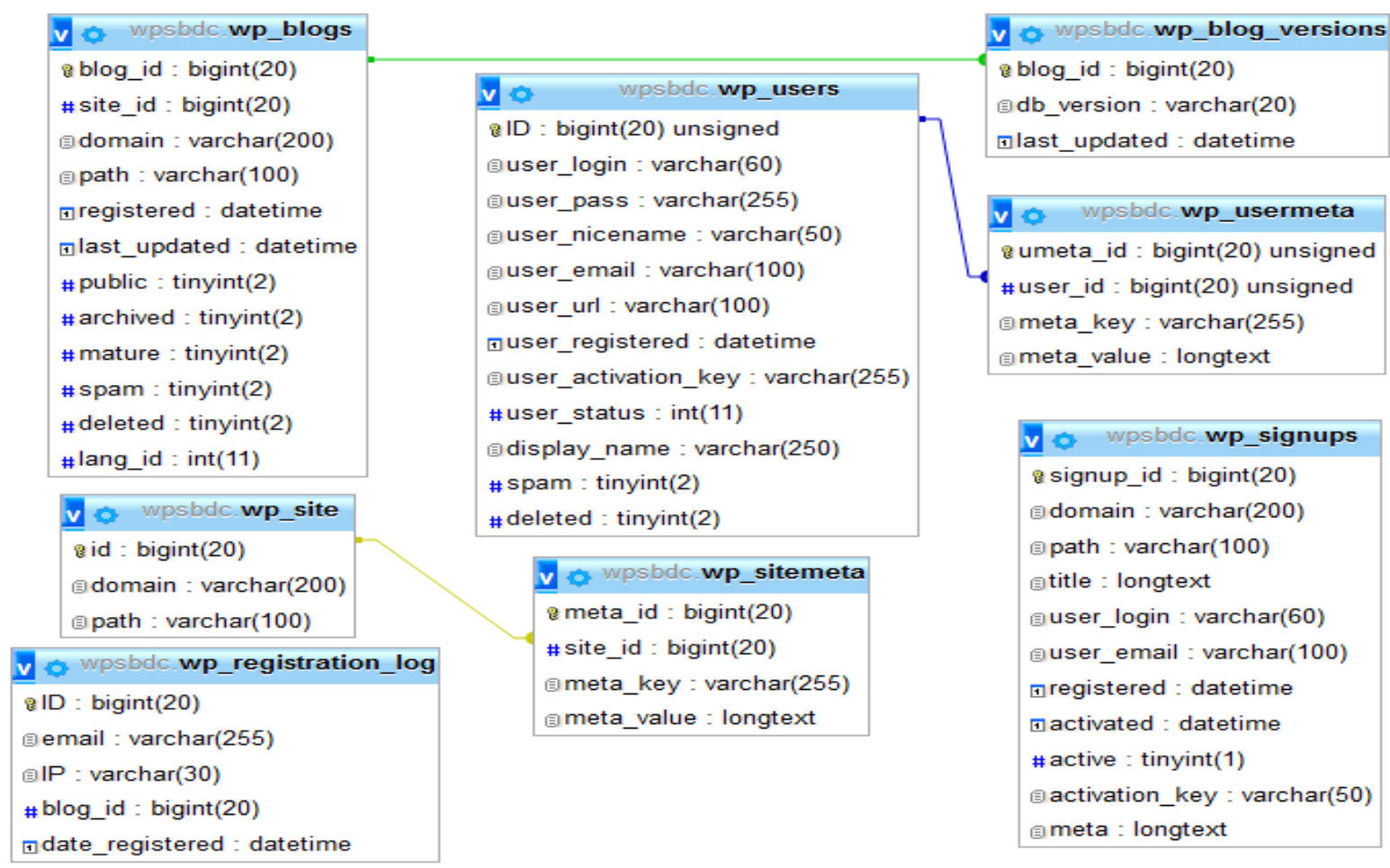

Image 4. Additional tables in the operational Database WordPress Multisite 


\section{Implementation}

The application of model learning Independent Study classes on iLearning harnesses

1. Display Access the iMe Class students in Independent Study

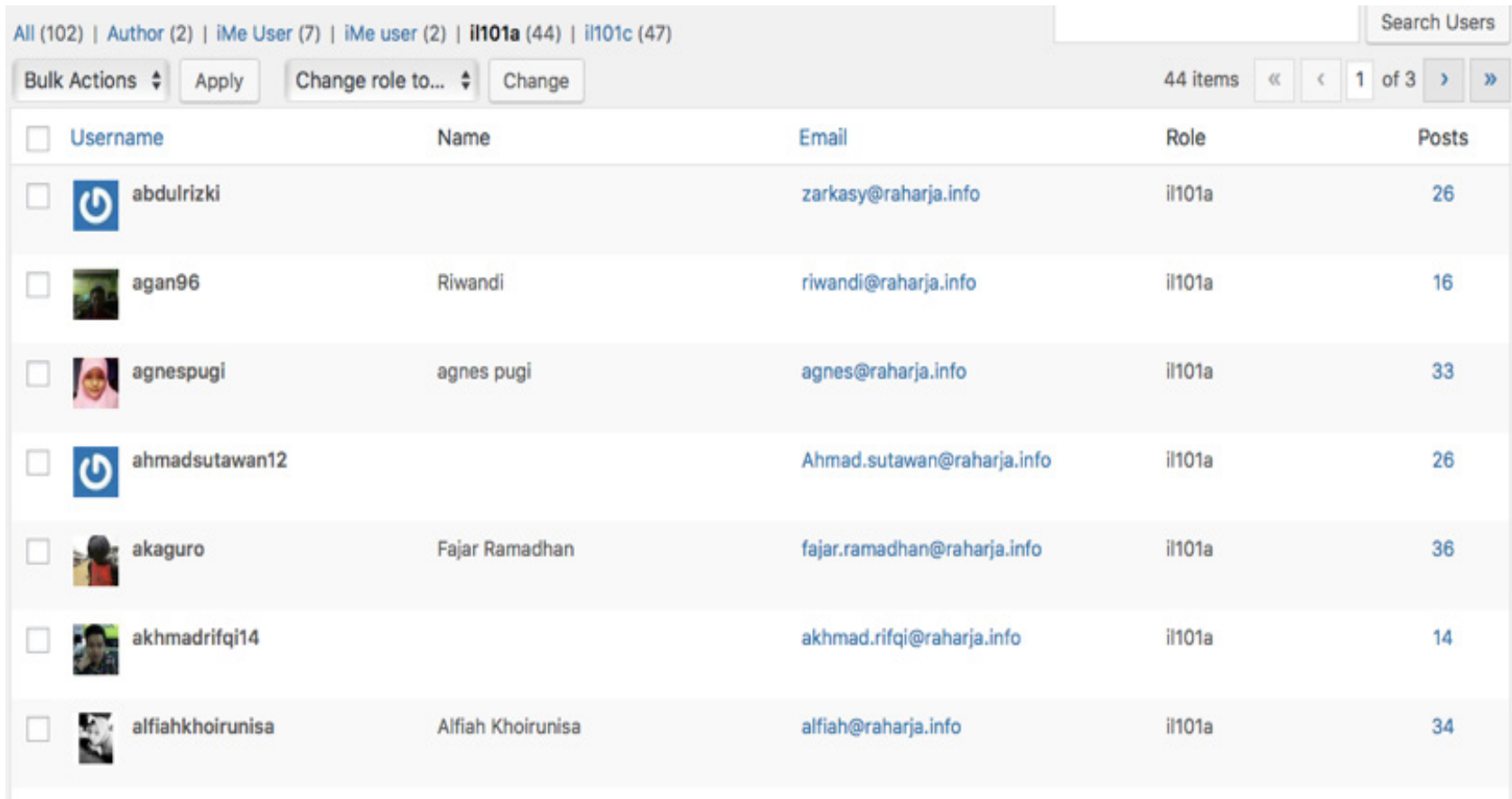

Image 5. Display Access Author Students in the iMe Class Independent Study

Image 5. Above is the look of the updated access students in the iMe class Independent Study, where the lecturer invites student to become an author in the iMe Class independent Study. Then students can start the activity in the classroom working on assignment-assignment given Professor iMe Class.

\section{Display Students Independent Study Class Mailing List}

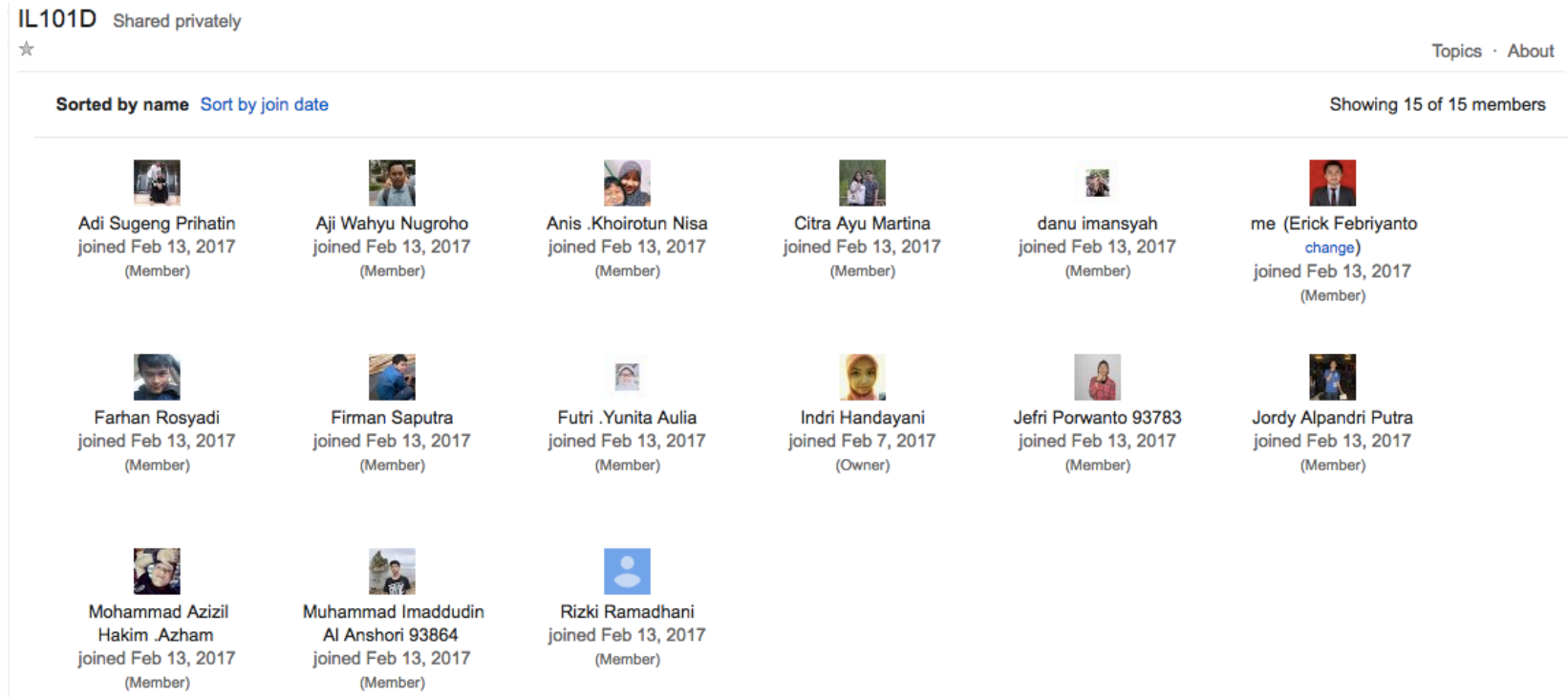

Image 6. Display the Grade Independent Study Students Mailing List 
3. Display the activity of Independent Study Classes Students mailing list

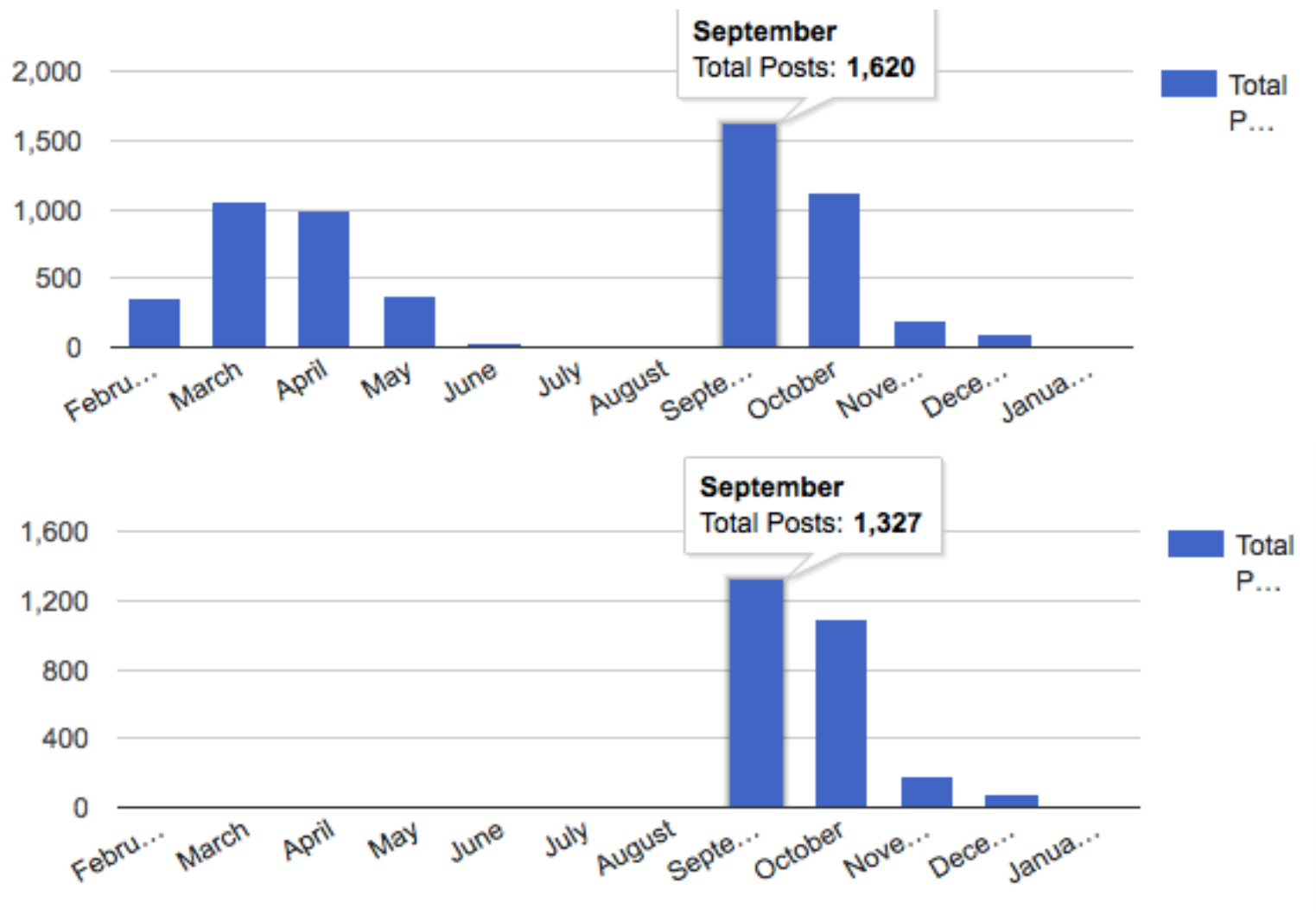

Image 7. Display The Grade Students Mailing List Activity Independent Study

4. Display the Homepage of iDu Class Independent Study

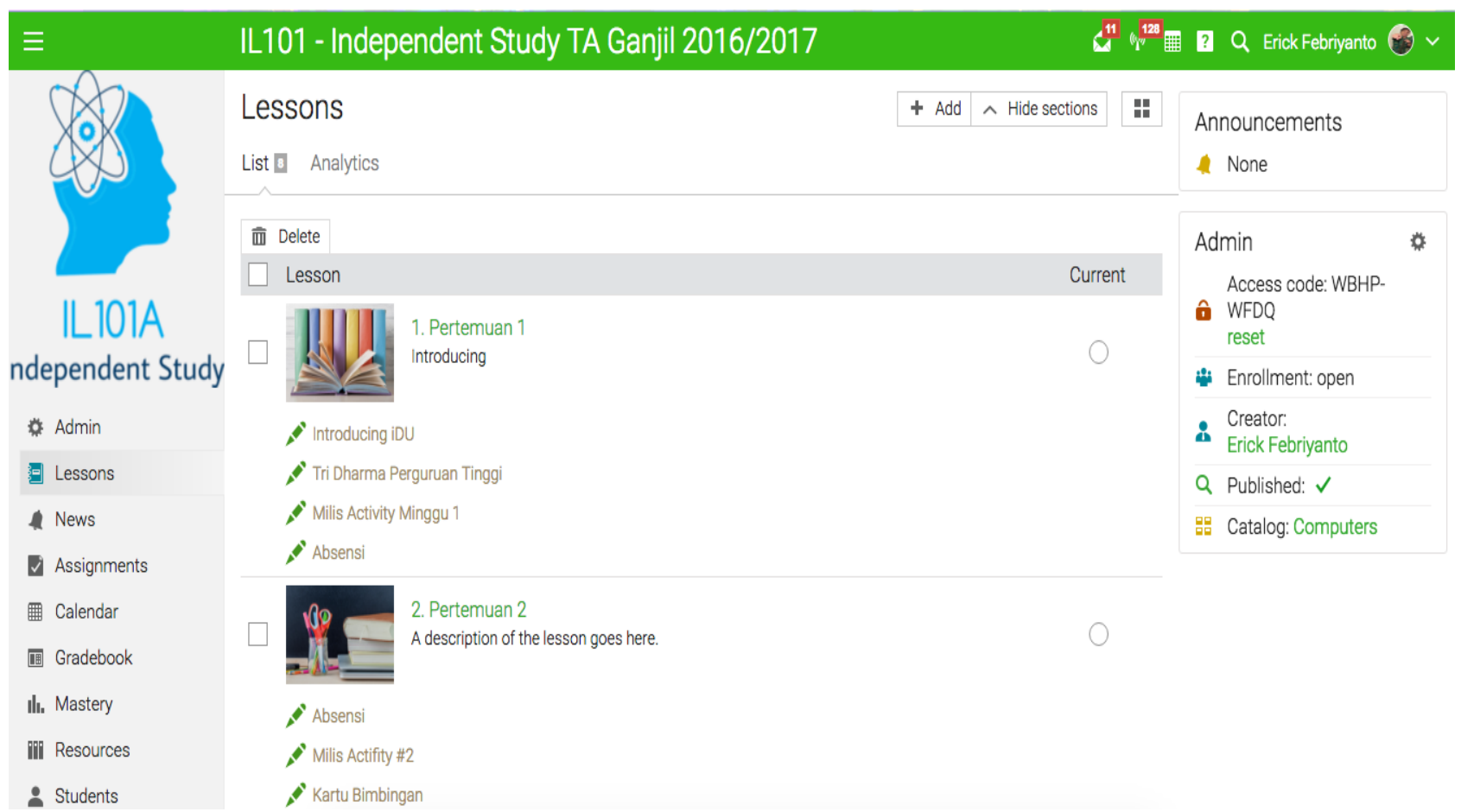

Image 8. Display the Homepage of iDu Class Independent Study 
5. Display Assignment iDu Class Independent Study

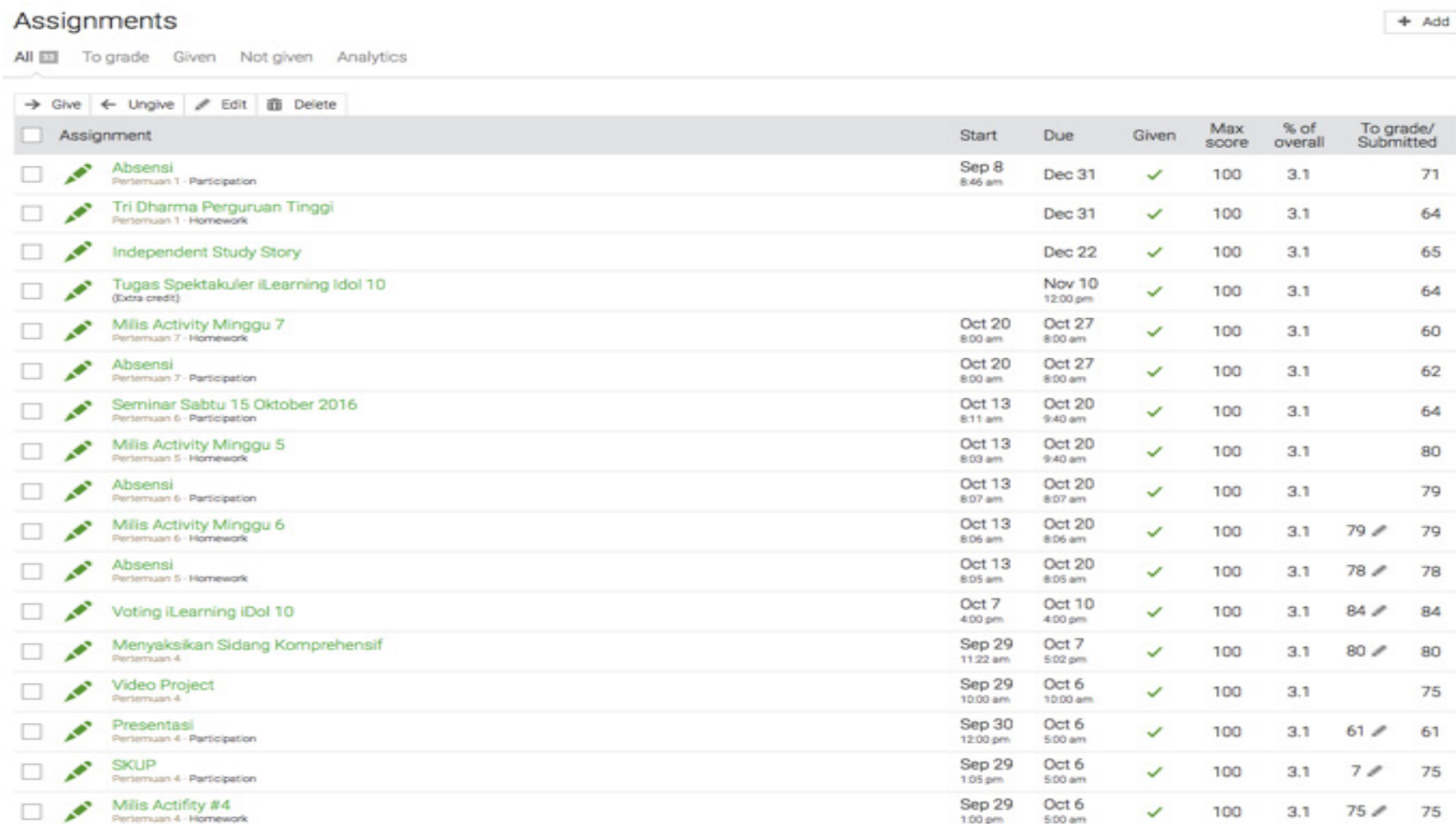

Image 9. Display Assignment iDu Class Independent Study

6. Display Viewboard activity of Students Independent Study Classes

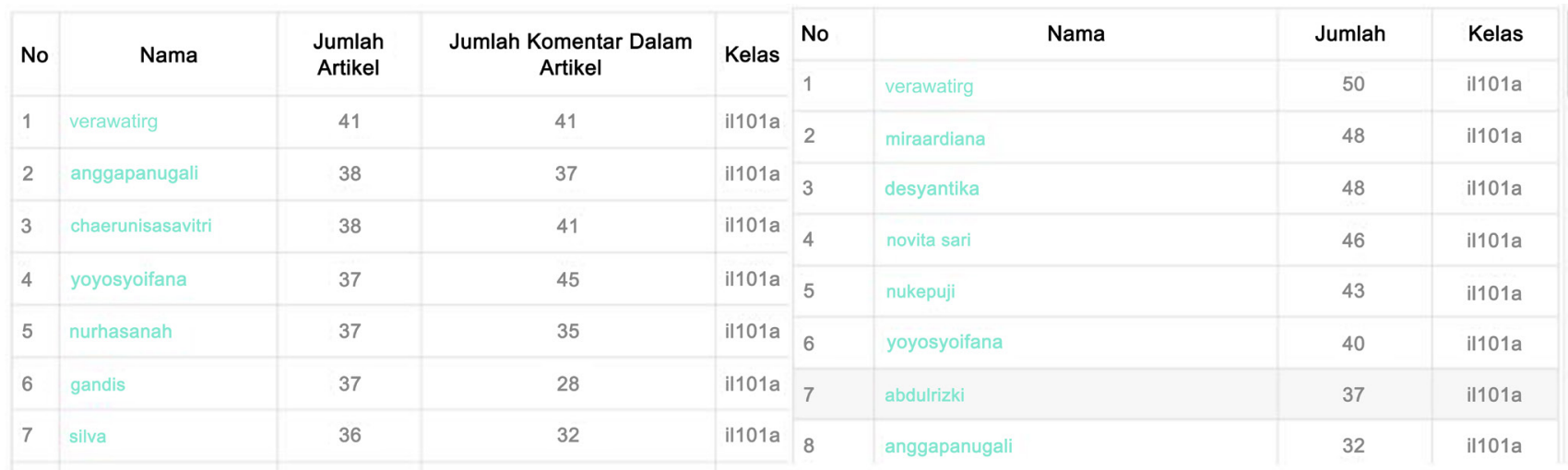

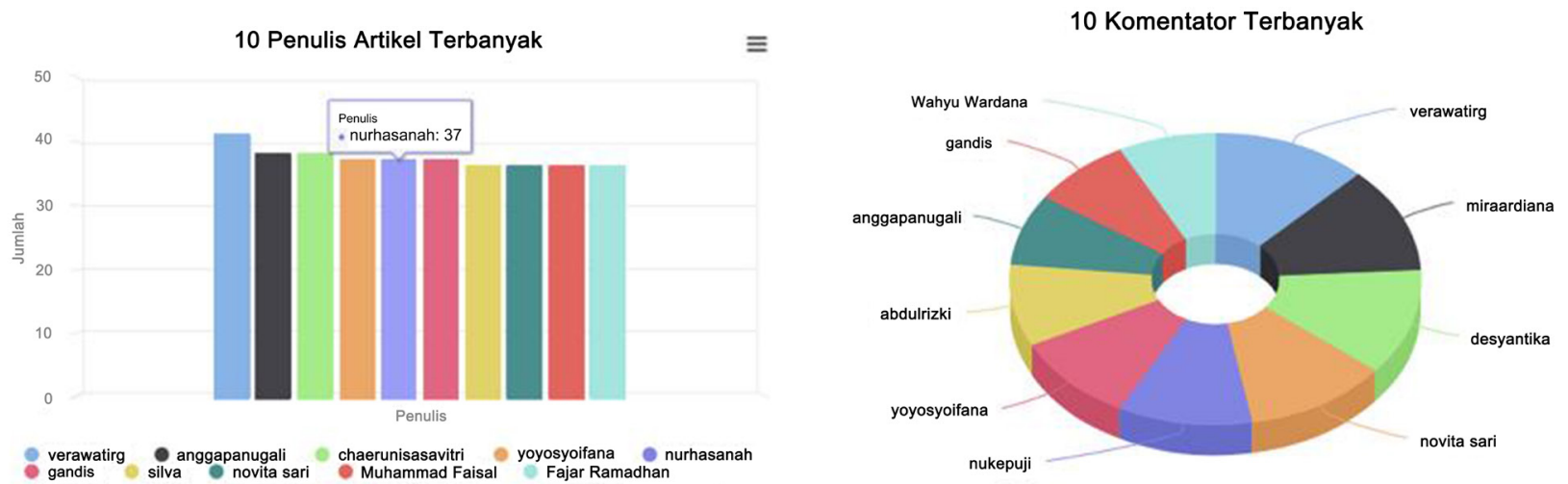

Image 10. Display the Grade Student Activity Viewboard Independent Study 
7. Viewboard Display Assignment On iDu Class Independent Study

\section{Gradebook}

Assignments by descending due $\checkmark$

\begin{tabular}{|c|c|c|c|c|c|c|c|c|c|c|c|c|c|}
\hline \multicolumn{3}{|l|}{ Assignments } & $\begin{array}{l}\text { Trionarma } \\
\text { Pergone. }\end{array}$ & Absensi & $\begin{array}{l}\text { independen } \\
\text { t Suuty- }\end{array}$ & $\begin{array}{l}\text { Tugas soek } \\
\text { twikuler. }\end{array}$ & Absensil & $\begin{array}{l}\text { Mils Activit } \\
\text { y Min. }\end{array}$ & $\begin{array}{l}\text { Mils Active } \\
\text { y Min. }\end{array}$ & $\begin{array}{c}\text { Seminar Sa } \\
\text { btu 150. }\end{array}$ & Absensil & $\begin{array}{c}\text { Miśacesit } \\
\text { Y Min. }\end{array}$ & Absensi \\
\hline \multicolumn{3}{|c|}{ Categary } & Homew. & Parti. & . & . & Part. & Homew. & Homew. & Parti. & Parti. & Homew. & Homew. \\
\hline \multicolumn{3}{|c|}{ Due } & Dec 31 & Dec 31 & Dec 22 & Nov 10 & $\operatorname{Oet} 27$ & Oet 27 & Oet 20 & Oet 20 & Oet 20 & Oet 20 & Oet 20 \\
\hline Students & \multicolumn{2}{|c|}{ Overall } & 100 & 100 & 100 & $100 / \mathrm{ec}$ & 100 & 100 & 100 & 100 & 100 & 100 & 100 \\
\hline (O) aditya, anggun & $95 \%$ & At & 100 & 100 & 100 & 100 & 100 & 100 & 100 & 100 & 100 & 100 & 100 \\
\hline 2 Agustin, Devi & $29 \%$ & $F$ & 100 & 0 & 100 & 100 & M & M & 100 & 100 & 100 & 100 & 100 \\
\hline (9) agustina gandis & $100 t$ & At & 100 & 100 & 100 & 100 & 100 & 100 & 100 & 100 & 100 & 100 & 100 \\
\hline (2) All Muhamad & $46 \%$ & D & 100 & $\mathrm{M}$ & 100 & M & M & M & 100 & 100 & 100 & 100 & 100 \\
\hline (9) Andriani, Dina 13 & $94 \%$ & A & 100 & 100 & 100 & 100 & 100 & 100 & 100 & 100 & 100 & 100 & 100 \\
\hline 6 anisa, nike & $34 \%$ & $F$ & 100 & 100 & M & M & 100 & M & M & M & M & M & M \\
\hline e. Anjani, Dwi & $100 \%$ & At & 100 & 100 & 100 & 100 & 100 & 100 & 100 & 100 & 100 & 100 & 100 \\
\hline Q antika, desy & $52 \pi$ & $\mathrm{D}+$ & M & M & M & M & M & M & 100 & M & 100 & 100 & 100 \\
\hline A arbiyanto, deny & $63 \pi$ & c & 100 & 100 & 100 & 100 & M & M & 100 & 100 & 100 & 100 & 100 \\
\hline (A) Ardiana, Mira & $95 \%$ & At & 100 & 100 & 100 & 100 & 100 & 100 & 100 & 100 & 100 & 100 & 100 \\
\hline (1) aula, hagigi & $57 x$ & c. & M & M & $M$ & M & 100 & 100 & 100 & M & 100 & 100 & 100 \\
\hline 2 ayulestari, silva & $106 \%$ & At & 100 & 100 & 100 & 100 & 100 & 100 & 100 & 100 & 100 & 100 & 100 \\
\hline $\mathbf{6}$ azij, rifki & $54 \%$ & D+ & M & 100 & $M$ & 100 & 100 & 100 & 100 & M & $M$ & 100 & M \\
\hline - azis, Privatna abdul & $92 \pi$ & A & 100 & 100 & M & $\mathrm{M}$ & 100 & 100 & 100 & 100 & 100 & 100 & 100 \\
\hline
\end{tabular}

Image 11. Display Viewboard Assignment On iDu Class Independent Study

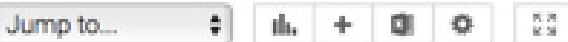




\section{Conclusions}

By using the iLearning Media (iMe) accompanied the concept and the business intelligence dashboard by adding on the system, it can be stated that the enthusiastic students in productivity as well as good interaction of lecturers to students or between students that can be measured and proven learning process further enhance motivation. By using the iLearning Education (iDu) accompanied the concept and tools business intelligence with dashboard on the system, it can be stated that the assessment to students more objectives both from lecturer to student or vice versa can be measured and proved that improve the quality of assessments. The system can measure the effectiveness of implemented learning with proven empirically valid questionnaires through data and reliability. Both in terms of Readiness, Accurate dimensions, and Timeliness.

\section{REFERENCES}

[1] Hamdani, 2011. Strategi Belajar Mengajar. Bandung: CV Pustaka Setia.
[2] Luo, Guo-Heng, Liu, Eric, Zhi-Feng, Kuo, Hung-Wei, Yuan, Shyan-Ming, 2014. Design and Implementation of a Simulation-Based Learning System for International Trade. Athabasca, AB T9S 3A3 Canada, International Review of Research in Open and Distance Learning (IRRODL) Vol. 15 Athabasca University. Diakses dari http://www.irrodl.org/index.php/irrodl/article/view/1666/281 6 Tanggal 23 Januari 2016 Pukul 03.55 WIB.

[3] Rahardja, Untung, Desrianti, Dewi, Immaniar, Mawadah, Siti, 2011. iBooks Standardisation and Good Practice for Effective Education Methods Insupport of iLearning. Tangerang, CCIT Journal Vol. 5 STMIK Raharja.

[4] Rahardja, Untung., Tiara, Khanna., \& Wijaya, RIT. (2014). Penerapan Rinfo Sebagai Media Pendukung Untuk Proses Pembelajaran Pada Perguruan Tinggi Raharja. CCIT Journal, $8(1)$.

[5] Pardede, Timbul. (2011). Pemanfaatan E-Learning Sebagai Media Pembelajaran Pada Pendidikan Tinggi Jarak Jauh. Prosiding Seminar FMIPA UT. (Online), (www.pustaka.ut.ac.id/).

[6] Henderi, Yusup, Muhamad, Rantama, Yulika, Ayu, 2013. Penggunaan Metode iLearning untuk Meningkatkan Kualitas Pembelajaran di Perguruan Tinggi. Tangerang, CCIT Journal Vol. 6 STMIK Raharja. 